\title{
New Occurrences of Social Wasps (Hymenoptera: Vespidae) in Semideciduous Seasonal Montane Forest and Tropical Dry Forest in Minas Gerais and in the Atlantic Forest in the State of Rio de Janeiro
}

\author{
Marcos Magalhães Souza1, Epifânio Porfiro Pires², Rafael Eugênioº \& Reinildes Silva-Filho
}

1. Instituto Federal de Educação e Tecnologia do Sul de Minas, Campus Inconfidentes (Biologia), Inconfidentes - MG, e-mail: marcoscajubi@gmail.com (Autor para correspondência ${ }^{\varpi}$ ). 2. Departamento de Entomologia (DEN) Universidade Federal de Lavras (UFLA), e-mail: epifaniopires@yahoo.com.br. 3. Instituto Federal de Educação e Tecnologia do Sul de Minas, Campus Inconfidentes, Inconfidentes - MG, e-mail: rafaeugenio@yahoo.com.br, 4. EcoSystems Jardins Comércio e Serviços Ltda - Rio de Janeiro, e-mail: rennefilho@gmail.com.

\section{EntomoBrasilis 8 (1): 65-68 (2015)}

Registered in ZooBank: urn:lsid:zoobank.org:pub: BoB7155A-3259-4A32-8719-ED91BA42608B

Abstract. The occurrence of Mischocyttarus consimilis Zikán, Mischocyttarus ignotus Zikán, Mischocyttarus nomurae Richards and Mischocyttarus paraguayensis Zikán for the state of Minas Gerais and Mischocyttarus garbei Zikán for the state of Rio de Janeiro are registered for the first time, collected through active search and attractive traps.

Keywords: Distribution; Polistinae; Survey; Taxonomy.

\section{Novos Registros de Vespas Sociais (Hymenoptera: Vespidae) em Floresta Estacional Semidecidual Montana e Mata Seca em Minas Gerais e na Mata Atlântica no Estado do Rio de Janeiro}

Resumo. Neste trabalho é registrado pela primeira vez a ocorrência de Mischocyttarus consimilis Zikán, Mischocyttarus ignotus Zikán, Mischocyttarus nomurae Richards e Mischocyttarus paraguayensis Zikán para o estado de Minas Gerais e Mischocyttarus garbei Zikán para o estado do Rio de Janeiro coletadas por meio de busca ativa e armadilhas atrativas.

Palavras-Chave: Distribuição; Levantamento; Polistinae; Taxonomia.

$\mathrm{BB}$ iodiversity should not be evaluated in terms of number of species, but also on the perspective of interactions and species distribution, to enhance the preservation of natural ecosystems (DeL-Claro 2004). In this regard, the biological characteristics, distribution, abundance and richness of social wasp interactions make them a key group in ecosystems with important ecological roles as predators (RICHTER 2000; ELISEI et al. 2005; Prezoto et al. 2005; Prezoto et al. 2006; SANTOs et al. 2007a; SANTos et al. 2009), bioindicators (SouZA et al. 2010a) and pollinators (Heithaus 1979; Hermes \& KoHLer 2006; Santos et al. 2009).

In Brazil, despite the great diversity of social wasps, little is known about their ecology and distribution along the Brazilian biomes (Richards 1978; Carpenter \& Marques 2001; Souza \& ZANUNCIO 2012).

In the last decade, social wasp diversity studies have been conducted in a semideciduous forest in the state of Minas Gerais (Souza \& Prezoto 2006; Elpino-Compos 2007), although not including the regions South and Zona da Mata. There are also no records of studies on these insects for the tropical dry forest in Minas Gerais, and the coastal region of Rio de Janeiro state. The goal of this study was to provide information about the occurrences of social wasps in two Brazilian ecosystems, the Atlantic Forest and tropical dry forest, in the states of Minas Gerais and Rio de Janeiro.

The study was conducted in the municipality of São Gonçalo do
Sapucaí ( $\left.21^{\circ} 53^{\prime} 20^{\prime \prime} \mathrm{S}, 45^{\circ} 35^{\prime} 24^{\prime \prime} \mathrm{W}\right)$, southern Minas Gerais, in areas of semideciduous seasonal montane forest in the period from March 2012 to February 2013; in the Parque Estadual do Brigadeiro $\left(2042^{\prime} 55^{\prime \prime} \mathrm{S}, 4226^{\prime} 51^{\prime \prime} \mathrm{W}\right)$, forestzone of Minas Gerais, in the period from January to December 2011, in semidecidual seasonal montana forest formations, in the municipality of Montes Claros ( $16^{\circ} 44^{\prime} 13$ ”'S, $43^{\circ} 51^{\prime} 53^{\prime \prime}$ W), northern Minas Gerais state, tropical dry forest area, November-December 2011, and in the Atlantic Forest in the district of Trindade $\left(20^{\circ} 31^{\prime} 29^{\prime \prime} \mathrm{S} 29^{\circ}\right.$ 19'29" W), municipality of Paraty, State of Rio de Janeiro in October 2009 (Figure 1).

The collection of social wasp species was conducted using the methodology of active search (entomological net) and attractive traps (using passion fruit, guava, mango and sardines) (Silveira 2002; SouZA \& PREZOTO 2006).

The social wasp species were identified with the aid of identification keys and comparison with specimens from the entomological collection of the Entomology Department of Universidade Federal de Lavras (UFLA) and/or by Prof. Dr. Orlando Tobias da Silveira of the Emílio Goeldi Museum, Belém, Pará. Specimens were deposited in the Emilio Goeldi Museum and the entomological collection of the Federal Universities of Viçosa and Lavras.

Funding Agencies: Holcim Cimento Barroso and CAPES 
T New records for the state of Minas Gerais are Mischocyttarus consimilis Zikán; Mischocyttarus ignotus Zikán; Mischocyttarus nomurae Richards and Mischocyttarus paraguayensis Zikán (Hymenoptera: Vespidae), the first species being unprecedented in Brazil (RICHARDS 1978), increasing from 96 to 100 species of social wasps for the state (SouZA \& ZANUNCIO 2012). One new record for the state of Rio de Janeiro is Mischocyttarus garbei Zikán (Hymenoptera: Vespidae) (Figure 1).

We recorded seven colonies of $M$. consimilis (Figure 2) in the municipality of São Gonçalo do Sapucaí. Nesting occurred on different substrates, such as banks, leaves and roots. This species had previously been recorded only in the state of Mato Grosso do Sul (Richards 1978; Torres et al. 2011). There was a record of an M. ignotus nest (Figure 3) also in São Gonçalo do Sapucaí, nesting inside the forest. This species was previously recorded for the states of São Paulo and Rio Grande do Sul (RichARDS 1978).

Although the genus Mischocyttarus forms the largest group of social wasps, with nine subgenera and 245 species, the registration of new collecting records of this genus is due to a sum of factors such as small nests and few individuals, which together with little studied regions like Atlantic Forest areas, increases the chance of unprecedented registrations (COOPER 1998; SIlveIRA 2008).

The registration of the M. nomurae occurred in December 2011, which corresponded to the rainy season, when five specimens were captured using an attractive trap with passion fruit in the city of Montes Claros, Minas Gerais, there being no record of the colonies. Several studies show the effectiveness of this bait (Souza \& Prezoto 2006; Noll \& Gomes 2009; Souza et al. 2010b; SouzA et al. 2012) as an attractive source to capture social wasps, through the olfactory signals due to the strong fragrance emitted by the fruit (COLLET et al. 2003; NAUG \& WENZEL 2006; WARRANT et al. 2006; McPheron \& Mills 2007; SANTos et al. 2007b).
Mischocyttarus paraguayensis was recorded in São Gonçalo do Sapucaí, with the only registered colony built on a plant substrate. In Parque Estadual do Brigadeiro this species was also sampled, and only one colony recorded (Figure 4). The species also occurs in the states of Rio Grande do Sul and Santa Catarina (RichaRdS 1978).

A colony of $M$. garbei (Figure 5) was recorded in a Bromeliaceae in the rainy season in the district of Trindade, municipality of Paraty, Rio de Janeiro. Bromeliads have very rigid leaves and are possibly shelter for their nests against the action of rain, a situation already recorded in other plant species in Minas Gerais, such as the species Mischocyttarus confusus (Zikán) in Mrytaceae in Cerrado areas, Protopolybia sedula (Saussure) in Bromeliacae in a rupestrian field (Souza \& Prezoto 2006; SouzA et al. 2010b), and Protopolybia sp. and Polybia platycephala (Richards) on ornamental plants in public gardens (РREzoтo et al. 2009). This species has only been registered in the state of Espírito Santo (RICHARDS 1978).

These new distribution records of social wasps in the states of Minas Gerais and Rio de Janeiro suggest that many species are still unknown to these states. Despite efforts to know the diversity of social wasps in Minas Gerais in the last decade, the number of species should be higher, considering the territorial state size, and the fact that some ecosystems are not sampled in an expressive way. For the state of Rio de Janeiro, there are few areas studied, considering the existence of large Atlantic Forest fragments, suggesting that the number of species should also be larger than currently known.

In this sense, it is worth emphasizing the importance of further studies in these states in order to obtain specific information from these larger bodies, which will surely increase the knowledge of the social wasp fauna.

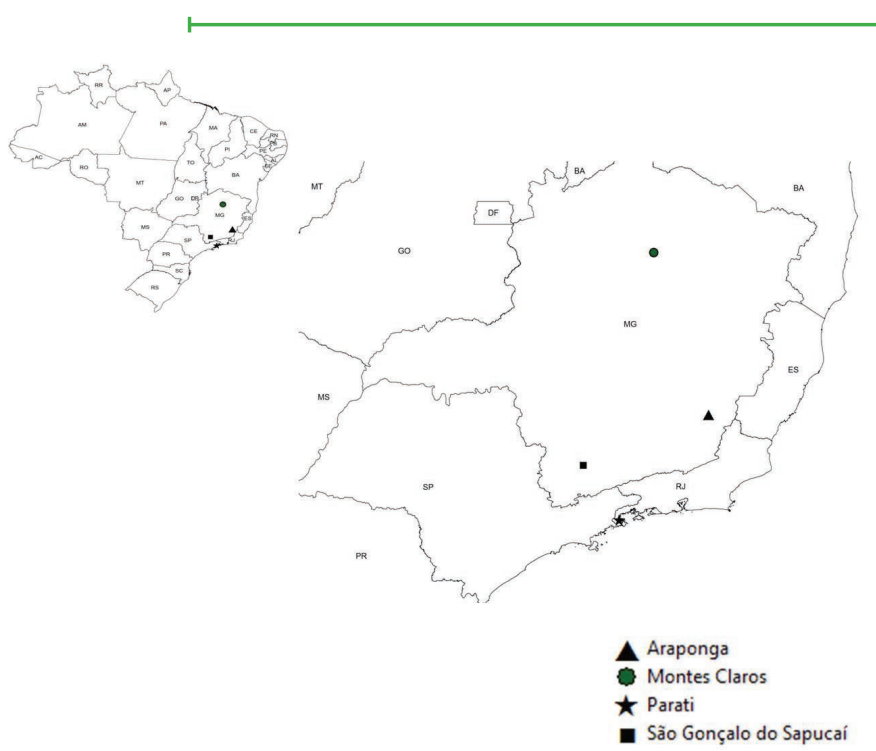

Figure 1. Localization of sampling areas in the states of Minas Gerais and Rio de Janeiro. Symbols indicate the municipalities where the species of social wasps (Hymenoptera: Vespidae) were recorded.

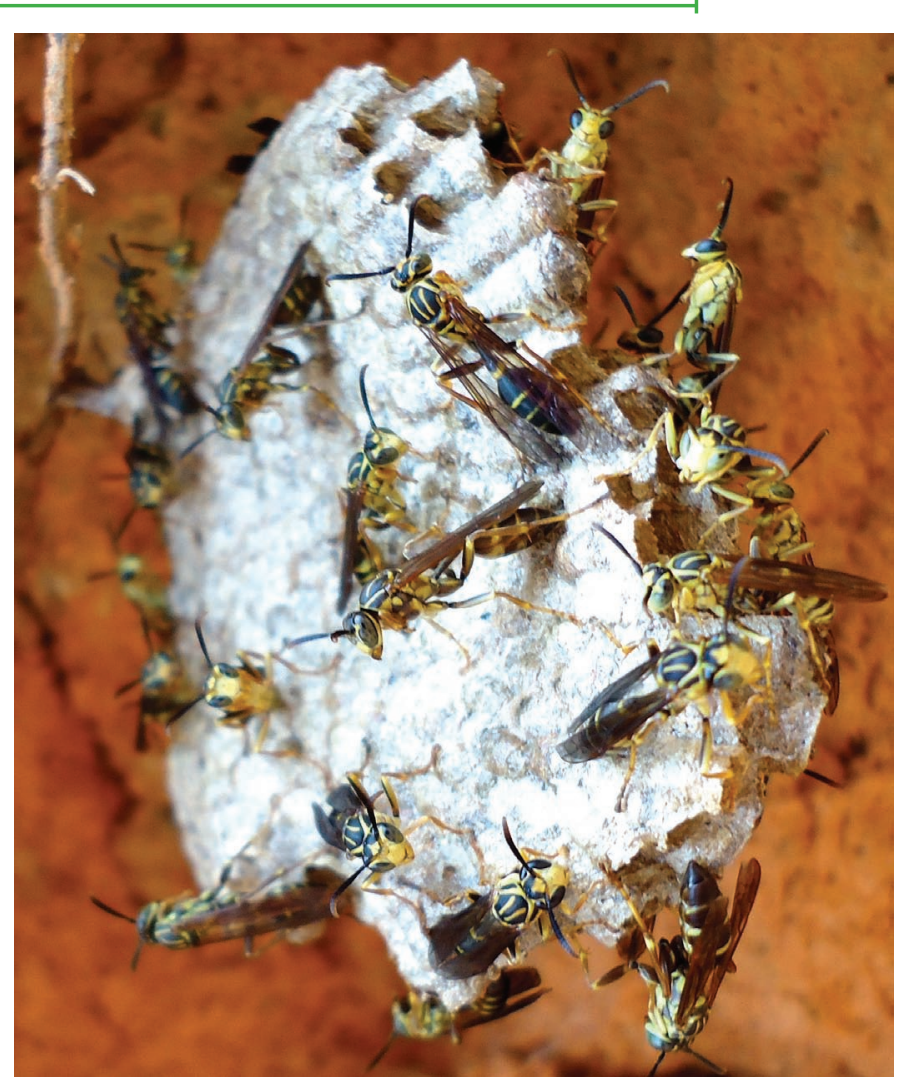

Figure 2. Nests of the wasp Mischocyttarus consimilis Zikán in the municipality of São Gonçalo do Sapucaí, Minas Gerais. 

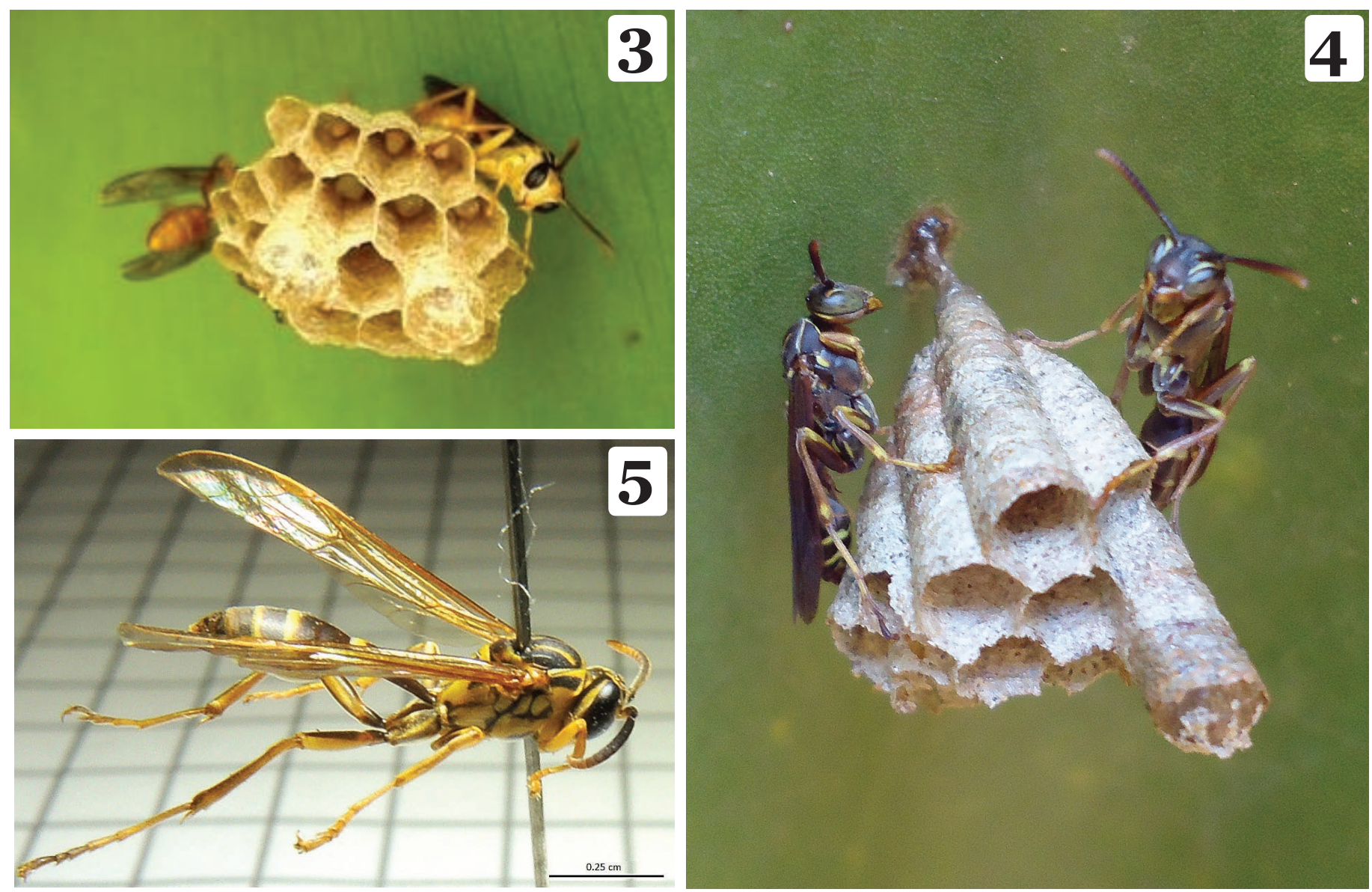

Figure 3. Wasp Mischocyttarus ignotus Zikán in the municipality of São Goncalo do Sapucaí, Minas Gerais.

Figure 4. Nests of the wasp Mischocyttarus paraguayensis Zikán in Parque Estadual do Brigadeiro, Minas Gerais.

Figure 5. Nests of the wasp Mischocyttarus garbei Zikán in Trindade, Paraty, Rio de Janeiro.

\section{ACKNOWLEDGMENTS}

We thank Orlando Tobias Silveira for species identification and the company Holcim Cement Barroso for assistance in transportation.

\section{REFERENCES}

Carpenter, J. M. \& Marques, O. M. 2001. Contribuição ao estudo de vespídeos do Brasil (Insecta, Hymenoptera, Vespoidea, Vespidae). Cruz das Almas, Universidade Federal da Bahia. Série Publicações digitais. v. 2, versão 1.o. 1 CD-ROM.

Collet, T.S., P. Graham \& V. Durier, 2003. Route learning by insects. Current Opinon Neurobiologic, 13: 718-725.

Cooper, M., 1998. New species of the artifex group of Mischocyttarus de Saussure (Hymenoptera: Vespidae) with a partial key. Entomologist's Monthly Magazine, 134: 293306.

Del-Claro, K., 2004. Mulitrophic relationships, conditional mutualisms, and the study of interaction biodiversity in Tropical Savannas. Neotropical Entomology, 33: 665-672.

Elisei, T., C. Ribeiro Júnior, D.L. Guimarães \& F. Prezoto, 2005. Foraging activity and nesting of swarm-founding wasp Synoeca cyanea (Fabricius, 1775) (Hymenoptera, Vespidae, Epiponini). Sociobiology, 46: 317-327.

Elpino-Campos, A., K. Del-Claro \& F. Prezoto, 2007. Diversity of social wasps (Hymenoptera: Vespidae) in Cerrado fragments of Uberlândia, Minas Gerais State, Brazil. Neotropical Entomology, 36: 685-692.

Heithaus, E. R., 1979. Community structure of Neotropical flower visiting bees and wasps: Diversity and phenology. Ecologia, 60: $190-202$

Hermes, M.G. \& A. Kohler, 2006. The flower-visiting social wasps (Hymenoptera, Vespidae, Polistinae) in two areas of Rio Grande do Sul, southern Brazil. Revista Brasileira de Entomologia, 50: 268-274.
McPheron, L.J. \& N.J. Mills, 2007. Influence of visual and olfactory cues on the foraging behavior of the paper wasp Mischocyttarus flavitarsis (Hymenoptera: Vespidae). Entomologia Generalis, 30: 105-118.

Naug, D. \& J. Wenzel, 2006. Constraints on foraging success due to resource ecology limit colony productivity in social insects. Behavioral Ecology and Sociobiology, 60: 62-68.

Noll, F.B. \& B. Gomes, 2009. An improved bait method for collecting Hymneoptera, especially social wasps (Vespidae: Polistinae). Neotropical Entomolgy, 38: 477-481.

Prezoto, F., H.H.S. Prezoto, V.L. Machado \& J.C. Zanuncio, 2006. Prey captured and used in Polistes versicolor (Olivier) (Hymenoptera: Vespidae) nourishment. Neotropical Entomology, 35: 707-709.

Prezoto, F., M.A.P. Lima \& V.L.L. Machado, 2005. Survey of preys captured and used by Polybia platycephala (Richards) (Hymenoptera: Vespidae, Epiponini). Neotropical Entomology, 34: 849-851.

Prezoto, F., M.M. Souza, A. Elpino-Campos \& K. Del-claro, 2009. First Record of occurrence to eight species of social wasps (Hymenoptera, Vespidae) in the Semideciduous forest and cerrado (savanna) regions in Brazil. Sociobiology, 54: 759764.

Richards, O.W., 1978. The social wasps of the Americas. London: British Museum of Natural History, $580 \mathrm{p}$.

Richter, M.R., 2000. Social wasp (Hymenoptera: Vespidae) foraging behavior. Annual Review of Entomology, 45: 121150.

Santos, G.M.M., C.C. Bichara-Filho, J.J. Resende, J.D. Cruz \& O.M. Marques, 2007b. Diversity and community structure of social wasps (Hymenoptera: Vespidae) in three ecosystems in Itaparica Island, Bahia State, Brazil. Neotropical Entomology, 36: $180-185$.

Santos, G.M.M., P.C. Bispo \& C.M.L. Aguiar, 2009. Fluctuations in richness and abundance of social wasps during the dry and 
wet seasons in three phyto-physiognomies at the Tropical Dry Forest of Brazil. Environmental Entomology, 38: 1613-1617.

Santos, G.M.T., Alves, A.A. \& F.A.S. Mendonça, 2007a. Morfologia de estruturas sensoriais em pernas e antenas de Agelaia pallipes(Olivier), Polybia paulista (Ihering) e Mischocyttarus cassununga (Ihering) (Hymenoptera: Vespidae). Neotropic Entomologic, 36: 868-873.

Silveira, O.T., 2002. Surveying Neotropical social wasps. An evaluation of methods in the "Ferreira Penna" Research Station (ECFPn), in Caxiuanã, PA, Brazil (Hymenoptera, Vespidae, Polistinae). Papéis Avulsos de Zoologia, 42: 299323.

Silveira, O.T., S.V. Costa-Neto \& O.F.M. Silveira, 2008. Social wasps of two wetland ecosystems in brazilian Amazonia (Hymenoptera, Vespidae, Polistinae). Acta Amazonica, 38: 333-344.

Souza, M.M. \& F. Prezoto, 2006. Diversity of social wasps (Hymenoptera, Vespidae) in Semideciduous forest and cerrado (savanna) regions in Brazil. Sociobiology, 47: 135147.

Souza, M.M. \& J.C. Zanuncio, 2012. Marimbondos-Vespas sociais (Hymenoptera: Vespidae). Viçosa, Editora UFV. 79p.

Souza, M.M., E.P. Pires, M. Ferreira, T.E. Ladeira, M. Pereira, A. Elpino-Campos \& J.C. Zanuncio, 2012. Biodiversidade de vespas sociais (Hymenoptera: Vespidae) do Parque Estadual do Rio Doce, Minas Gerais, Brasil. MG- Biota, 5: 4-20.
Souza, M.M., J. Louzada, J.E. Serrão \& J.C. Zanuncio, $2010 a$. Social wasps (Hymenoptera: Vespidae) as indicators of conservation degree of riparian forests in southeast Brazil. Sociobiology, 56: 1-10.

Souza, M.M., T.E. Ladeira, N.R.G.A. Assis, A. Elpino-Campos, P. Carvalho \& J.N.C. Louzada, 2010b. Ecologia de vespas sociais (Hymenoptera: Vespidae) no campo rupestre na Área de Proteção Ambiental, APA, São José, Tiradentes, MG. MGBiota, 3: 15-32.

Torres, V.O., T.S. Montagna, W.D. Fernandes \& W.F. AntonialliJunior, 2011. Colony cycle of the social wasp Mischocyttarus consimilis Zikán (Hymenoptera, Vespidae). Revista Brasileira de Entomologia, 55: 247-252.

Warrant, E.J., A. Kelber, R. Wallén \& W.T. Wcislo. 2006. Ocellar optics in nocturnal and diurnal bees and wasps. Arthropod Structure and Development, 35: 293-305.

\section{Received in: 05/28/2013 \\ Accepted in: 02/01/2015}

\section{Suggested citation:}

Souza, M.M., E.P. Pires, R. Eugênio \& R. Silva-Filho, 2015. New Occurrences of Social Wasps (Hymenoptera: Vespidae) in Semideciduous Seasonal Montane Forest and Tropical Dry Forest in Minas Gerais and in the Atlantic Forest in the State of Rio de Janeiro. EntomoBrasilis, 8 (1): $65-68$. Available in: doi:10.12741/ebrasilis.v8i1.359
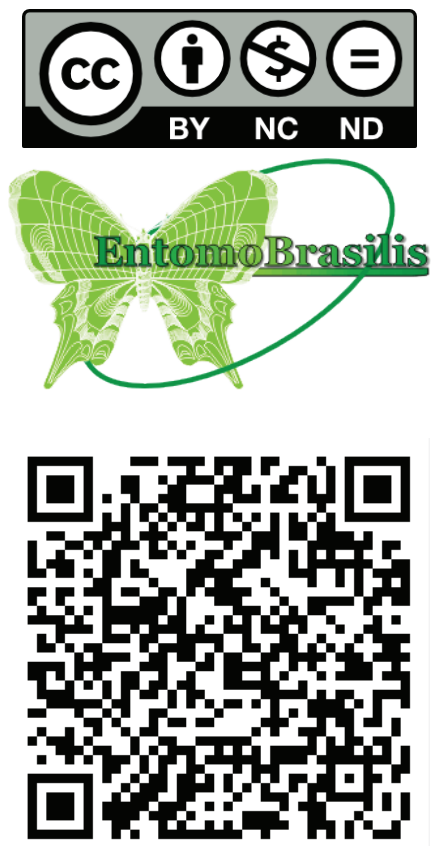